\title{
Tridentate hydrazido-hydrazones vanadium complexes. Synthesis, properties and biological activity
}

\author{
Janusz Szklarzewicza, ${ }^{a}$, Anna Jurowskaa, Maciej Hodorowicza, Dariusz Matogaa, Ryszard Grybośa, \\ Barbara Filipek ${ }^{\mathrm{b}}$, Jacek Sapa ${ }^{\mathrm{b}}$, Monika Głuch-Lutwin ${ }^{\mathrm{b}}$, Barbara Mordyl ${ }^{\mathrm{b}}$, Grzegorz Kazek ${ }^{\mathrm{b}}$ \\ a Jagiellonian University, Faculty of Chemistry, Gronostajowa 2, 30-387 Kraków, Poland \\ ' Jagiellonian University Medical College, Pharmacy, Medyczna 9, 30-001 Kraków, Poland
}

\section{Article history:}

Received 7 December 2018

Received in revised form

12 March 2019

Accepted 2 April 2019

Available online 2 April 2019

\begin{abstract}
Nine new vanadium complexes, with tridentate Schiff base ligand based on 3,5-di-tert-butyl-2-hydroxybenzaldehyde and different hydrazides, are described and characterized. The X-ray crystal structure of complex 8 shows distorted octahedral geometry of vanadium, with ONO ligand in equatorial position. The tridentate Schiff base ligand forms six membered and five-membered chelate rings at the $\mathrm{V}(\mathrm{V})$ acceptor center, with the corresponding bite angles being $82.97(9)^{\circ}$ and $74.48(9)^{\circ}$. The molecules are gathered by means of intermolecular $\mathrm{O}-\mathrm{H} \cdots \mathrm{N}$ hydrogen bond and layered by $\pi \cdots \pi$ interactions involving the pyridine and phenolate rings. Such interactions expand the structure along the crystallographic $a$ axis. The complexes were characterized by the elemental analyses, IR, UV-Vis, EPR spectroscopy, cyclic voltammetry, thermogravimetry and magnetic susceptibility measurements. The stabilization role of co-ligands is discussed. The cytotoxicity versus HepG2 hepatocytes and inhibition of human recombinant PTP1B was studied.
\end{abstract}

Keywords: vanadium, complex, Schiff base, structure, hydrazides, biological activity

\section{Introduction}

Schiff bases are an important class of ligands both in the medicinal and pharmaceutical fields. The coordination to vanadium spread the applications to such a biological activity as antibacterial, anti-inflammatory, antiviral, antifungal, anticancer and antipyretic properties [1-7]. One of the significant role of vanadium was found recently as decreasing the resistance to oncolytic immunotherapy [8]. On the other hand, chemistry and properties of vanadium complexes with Schiff bases allowed us to study the possible coordination modes of vanadium, stability of its oxidation states, role of co-ligands and the stability in solution $[9,10]$.

It has been also shown that vanadium compounds are potent inhibitors of phosphatases, especially protein tyrosine phosphatases such as PTP1B, TCPTP, PTP-MEG2, SHP-1, SHP-2, LAR [11-13]. This leads to the modulation of various cellular functions and may be the basis for the therapeutic use of vanadium compounds in metabolic, neoplastic, inflammatory, neurodegenerative and other diseases. The beneficial effects of vanadium compounds have been observed in studies using cells (including cancer) and in animal studies demonstrating the potential therapeutic efficacy of this group of phosphatase inhibitors.
Adverse and toxic effects of vanadium compounds have been observed in numerous preclinical, animal models during studies of pharmacological activity of vanadium compounds, mainly in antidiabetic and antitumor activity tests [14]. Numerous side and toxic effects of vanadium compounds affect most of the systems and organs of the body. This includes the respiratory, digestive and cardiovascular system as well as blood, brain, liver and kidneys. Vanadium also exhibit reproductive toxicity, influence on developmental processes and have potential to exert teratogenic and carcinogenic activity [15-17]. Several studies on preclinical animal models have provided strong evidence that the toxicity of vanadium compounds is related to several factors including species, dose, route and duration of administration as well as to the nature of the compound $[18,19]$. Organic vanadium compounds were recognised as much safer than inorganic vanadium salts [20] and antidiabetic potency and efficacy as well as toxicity may be modified by reasonable ligand binding of vanadyl ions [21]. The possibility of modulating the biological effects of vanadium (minimizing toxic effects and preserving the pharmacological activity) by modification the structure of organic ligands has been demonstrated by number of studies [22-24].

*Corresponding author: szklarze@chemia.uj.edu.pl, tel: 48-12-686-2504, fax: 48-12-686-2750 


\section{Materials and Methods}

[VO(acac) $)_{2}$, $\mathrm{VOSO}_{4} \mathrm{aq}$, 1,10-phenanthroline (phen), maltol, acetone, benzhydrazide, nicotinic hydrazide, phenylacetic hydrazide, 4-chlorobenzhydrazide, 2-hydroxybenzhydrazide, 3-hydroxy-2-naphthoic acid hydrazide, and 3,5-di-tert-butyl-2-hydroxybenzaldehyde (bald) were of analytical grade (Aldrich) and were used as supplied. Ethanol (98\%) of pharmaceutical grade was from Polmos and used as supplied. All other solvents were of analytical grade and were used as supplied. $\mathrm{BaSO}_{4}$ was of spectroscopic grade (Japan). $\mathrm{Bu}_{4} \mathrm{NPF}_{6}$ was synthesized from $\mathrm{Bu}_{4} \mathrm{NBr}$ and $\mathrm{KPF}_{6}$ by a standard method and recrystallized from acetone [25]. Microanalysis of carbon, hydrogen and nitrogen were performed using Elementar Vario MICRO Cube elemental analyzer. IR spectra were recorded on a Bruker EQUINOX 55 FT-IR spectrophotometer in $\mathrm{KBr}$ pellets. The electronic absorption spectra were recorded with Shimadzu UV-3600 UV-Vis-NIR spectrophotometer equipped with a CPS-240 temperature controller. Diffuse reflectance spectra were measured in $\mathrm{BaSO}_{4}$ pellets with $\mathrm{BaSO}_{4}$ as a reference on Shimadzu 2101PC equipped with an ISR-260 integrating sphere attachment. The magnetic susceptibility measurements were performed on a SHERWOOD SCIENTIFIC magnetic susceptibility balance. EPR spectra were recorded on a BRUKER ELEXSYS 500 using $9.419 \mathrm{GHz}$ microwave frequency. Cyclic voltammetry measurements were carried out in DMSO with $\left[\mathrm{Bu}_{4} \mathrm{~N}\right] \mathrm{PF}_{6}(0.1 \mathrm{M})$ as the supporting electrolyte, using Pt working and counter and $\mathrm{Ag} / \mathrm{AgCl}$ as reference electrodes on an $\mathrm{AU}$ TOLAB/PGSTAT $128 \mathrm{~N}$ Potentiostat/Galvanostat. $\mathrm{E}_{1 / 2}$ values were calculated from the average anodic and cathodic peak potentials, $\mathrm{E}_{1 / 2}=0.5\left(\mathrm{E}_{\mathrm{a}}+\mathrm{E}_{\mathrm{c}}\right)$. The redox potentials were calibrated versus ferrocene $(0.440 \mathrm{~V}$ versus $\mathrm{SHE})$, which was used as an internal potential standard for measurements in organic solvents to avoid the influence of a liquid junction potential; the final values are reported versus the standard hydrogen electrode (SHE).

Assessment of pharmacological activity included in vitro evaluation of PTP1B inhibition by an enzyme-based assay [26]. For determination the ability of tested compounds to inhibition of human recombinant PTP1B previously described method was used [26]. To the solution of the tested compounds on black 384well microplate wells (PerkinElmer) an equal volume of a test solution of phosphatase $50 \mathrm{ng} \mathrm{mL}-1$ PTP1B (1.5 U ml-1) was added in a reaction bu $\square$ er: $25 \mathrm{mM}$ of 3-(N-morpholino)propanesulfonic acid (MOPS), $50 \mathrm{mM} \mathrm{NaCl}, 1 \mathrm{mM}$ dithiothreitol (DTT) and $0.05 \%$ Tween-20, $\mathrm{pH} 7.0$. After 10 minutes, a solution of phosphate 6,8-difluoro-4-methyl (DiFMUP) was added until its final concentration was $0.1 \mathrm{mM}$. After 20 minutes of incubation at room temperature, the fluorescence intensity (excitation 355 and emission $560 \mathrm{~nm}$ ) was measured on a multifunctional plate reader POLARstar Omega (BMG Labtech, Germany).

Cytotoxicity assay was performed using PrestoBlue Cell Viability Reagent (ThermoFisher Scientific), a cell permeable resazurin-based reagent that functions as a cell viability indicator by using the reducing power of living cells (mitochondrial enzymes activity) to quantitatively measure the proliferation of cells. Human hepatocytes HepG2 seeded 18-24 hours before experiments in 96-well microplate (1x103 in $100 \mu \mathrm{l}$ DMEM with $10 \%$ FBS) were incubated with tested compounds at $37^{\circ} \mathrm{C}$ and $5 \% \mathrm{CO}_{2}$. After 24 hours incubation, $10 \mu \mathrm{l}$ of PrestoBlue reagent was added to each microplate well and microplate was mixed on orbital shaker. Plates were incubated for 20 minutes and the fluorescence intensity at $560 \mathrm{~nm}$ excitation and $590 \mathrm{~nm}$ emission was determined using multi-mode microplate reader POLARstar Omega (BMG Labtech, Germany). The results were normalized to the control (cells with solvent only), wherein the intensity of fluorescence was taken as $100 \%$.

Statistical analysis was performed by analysis of variance followed by the Tukey test for post hoc comparisons using GraphPad Prism 6.0 software (GraphPad Software, USA).

\section{Synthesis}

In Table 1 the ligand notation is shown.

Table 1. Schiff base ligands, formed in situ in reaction between 3,5-di-tert-butyl-2-hydroxybenzaldehyde (bald) and respective hydrazide, notation

\begin{tabular}{ll}
\hline Ligand notation & hydrazide \\
\hline $\mathrm{L}_{1}$ & benzhydrazide \\
$\mathrm{L}_{2}$ & 2-hydroxybenzhydrazide \\
$\mathrm{L}_{3}$ & phenylacetic hydrazide \\
$\mathrm{L}_{4}$ & 4-chlorobenzhydrazide \\
$\mathrm{L}_{5}$ & 3-hydroxy-2-naphtoic acid hydrazide \\
$\mathrm{L}_{6}$ & nicotinic hydrazide \\
\hline
\end{tabular}

\section{[VO(L) $($ maltol $)] \cdot \mathrm{H}_{2} \mathrm{O}, 1$}

The bald (0.351 g, $1.5 \mathrm{mmol})$ and the benzhydrazide (0.204 g, $1.5 \mathrm{mmol}$ ) were dissolved in $33 \mathrm{ml}$ of EtOH under Ar. The mixture was refluxed for 10 minutes under argon, next $\mathrm{VOSO}_{4} \mathrm{aq}$ ( $0.333 \mathrm{~g}, 1.5 \mathrm{mmol}$ ) was added and mixture was refluxed for 15 minutes. The solution becomes slowly dark. Then $10 \%$ from total $0.189 \mathrm{~g}$ ( $1.5 \mathrm{mmol})$ of maltol was added. After 5 minutes of reflux rest of the maltol was added. The solution becomes dark red. The reflux was then removed and $10 \%$ of solvent was evaporated under Ar. At this stage, formation of crystals was observed. The mixture was left for cooling. The formed dark red crystals were filtered off, washed with $\mathrm{EtOH}$ and water and dried in air. Yield: $0.540 \mathrm{~g}, 64 \%$. MW $=560.51$. Anal. Calcd. for $\mathrm{C}_{28} \mathrm{H}_{33} \mathrm{~N}_{2} \mathrm{O}_{7} \mathrm{~V}$ : C, 60.00; H, 5.93; N, $5.00 \%$. Found: C, $60.46 ; \mathrm{H}, 5.72 ; \mathrm{N}, 4.95 \%$. The complex is diamagnetic. FT-IR (KBr, cm ${ }^{-1}$ ): 3452 (w,br), 2963 (s), 2863 (w), 1622 (s), 1606 (s), 1591 (s), 1537 (m), 1515 (w), 1493 (w), 1462 (w), 1432 (m), 1349 (s), 1263 (vs), 1202 (s), 930 (m), 849 (m), 696 (s), 651 (w), 591 (w), 544 (w), 612 (s), 476 (m), [V=O] 978 (s). UV-Vis (DMSO): 
285, 340, $464 \mathrm{~nm},(\mathrm{MeCN}): 285,340,460 \mathrm{~nm},(\mathrm{MeOH}): 272$, $326,400 \mathrm{~nm}$.

\section{$\left[\left\{\mathrm{VO}\left(\mathrm{L}_{2}\right)(\mathrm{EtO})\right\}\left\{\mathrm{V}\left(\mathrm{L}_{2}\right)(\mathrm{EtO})_{2}\right\}(\mu-\mathrm{O})\right], 2$}

The complex was synthesized by us in 2010 by different method than that described in the literature [27]. The synthesis of the complex was under patent procedure and we could not published the results before 2017. The bald ( $0.352 \mathrm{~g}, 1.5 \mathrm{mmol})$, 2-hydroxybenzhydrazide $(0.228 \mathrm{~g}, 1.5 \mathrm{mmol})$ and $\mathrm{EtOH}(30 \mathrm{ml})$ were refluxed for 15 minutes (yellow solution was observed). Then $\mathrm{VOSO}_{4}$ aq $(0.333 \mathrm{~g}, 1.5 \mathrm{mmol})$ was added and mixture was refluxed for additional 90 minutes. The solution turned to dark yellow-brown and formation of yellow-brown precipitation was observed. The crystals were filtered off, washed with cold EtOH and dried in air. Yield: $0.554 \mathrm{~g}, 73 \%$. MW $=1002.98$. Anal. Calcd. for $\mathrm{C}_{50} \mathrm{H}_{68} \mathrm{~N}_{4} \mathrm{O}_{11} \mathrm{~V}_{2}$ : C, 59.88; H, 6.83; N, $5.59 \%$. Found: C, 60.08; H, 6.68; N, $5.67 \%$. The complex is diamagnetic. FTIR (KBr, cm ${ }^{-1}$ ): 3380 (w,br), 2965 (vs), 2862 (w), 1625 (vs), 1558 (m), 1523 (w), 1490 (m), 1463 (w), 1385 (w), 1361 (s), 1309 (w), 1272 (m), 1252 (vs), 1181 (m), 1091 (m), 1055 (s), 920 (m), 903 (m), 853 (m), 753 (s), 730 (m), 690 (w), 637 (m), 621 (m), 566 (w), 468 (w), [V=O] 993 (m), 957 (vs). UV-Vis (DMSO): 340, 416 nm, $(\mathrm{MeCN}): 277,342,460 \mathrm{~nm}$, (EtOH): 270, 338, $415 \mathrm{~nm}$.

\section{[VO $\left.\left(\mathrm{L}_{2}\right)_{2}\right] \cdot \mathrm{EtOH}, 3$}

The bald ( $0.541 \mathrm{~g}, 2.3 \mathrm{mmol}), 2$-hydroxybenzhydrazide $(0.351 \mathrm{~g}$, $2.3 \mathrm{mmol})$ and $\mathrm{EtOH}(30 \mathrm{ml})$ were refluxed under Ar for $15 \mathrm{~min}$ utes. Then $\mathrm{VOSO}_{4} \mathrm{aq}(0.513 \mathrm{~g}, 2.3 \mathrm{mmol})$ was added and reflux was continued for next 30 minutes. The dark green-brown product was started to precipitate. The solution was evaporated to ca $10 \mathrm{ml}$ under argon and left for cooling. The precipitate was filtered off under argon, washed with deareated acetone and dried under argon. Yield: 0.300 g, 31 \%. MW = 845.92. Anal. Calcd. for $\mathrm{C}_{46} \mathrm{H}_{58} \mathrm{~N}_{4} \mathrm{O}_{8} \mathrm{~V}$ : C, 65.31; H, 6.91; N, $6.62 \%$. Found: C, 65.29; $\mathrm{H}, 6.90 ; \mathrm{N}, 6.41 \%$. The complex is paramagnetic, $\mu=1.34 \mu_{\mathrm{B}}$. FT-IR (KBr, cm ${ }^{-1}$ ): 3458 (w,br), 2963 (vs), 2869 (w), 1623 (vs), 1589 (vs), 1535 (vs), 1487 (s), 1464 (m), 1426 (w), 1388 (m), 1363 (s), 1304 (w), 1251 (vs), 1180 (m), 1159 (m), 1030 (w), 914 (w), 829 (m), $783(\mathrm{~m}), 750$ (s), 725 (m), 661 (m), 615 (m), 563 (m), 476 (w), [V=O] 954 (w). UV-Vis (DMSO): 301, $370 \mathrm{~nm},(\mathrm{MeCN})$ : 284, 300, $363 \mathrm{~nm}$, (EtOH): 274, 303, $371 \mathrm{~nm}$.

\section{[VO $\left(\mathrm{L}_{3}\right)($ bald $\left.)\right], 4$}

The bald $(0.353 \mathrm{~g}, 1.5 \mathrm{mmol})$ and the phenylacetic hydrazide $(0.227 \mathrm{~g}, 1.5 \mathrm{mmol})$ in $50 \mathrm{ml}$ of EtOH were refluxed for $10 \mathrm{~min}$ utes under Ar. Then [VO(acac) $)_{2}$ (0.398, $\left.1.5 \mathrm{mmol}\right)$ was added and mixture was refluxed for 38 minutes giving very dark yellow transparent solution. This was then evaporated to ca. $20 \mathrm{ml}$ and left aside for crystallization. The next day black powder product was filtered off. Yield: $0.170 \mathrm{~g}, 34 \%$. MW $=665.76$. Anal. Calcd. for $\mathrm{C}_{38} \mathrm{H}_{50} \mathrm{~N}_{2} \mathrm{O}_{5} \mathrm{~V}: \mathrm{C}, \mathrm{C}, 68.55 ; \mathrm{H}, 7.57$; N, $4.21 \%$ Found: C, $68.35 ; \mathrm{H}, 7.39 ; \mathrm{N}, 4.38 \%$. The complex is diamagnetic. FT-IR
(KBr, cm $\left.{ }^{-1}\right): 3470$ (w,br), 2951 (vs), 2874 (w), 1650 (vs), 1609 (vs), 1559 (s), 1546 (s), 1528 (s), 1462 (m), 1434 (s), 1391 (m), 1361 (s), 1371 (m), 1266 (s), 1247 (vs), 1205 (m), 1172 (s), 1027 (w), 926 (w), 913 (w), 848 (s), 811 (w), 758 (m), 729 (s), 645 (w), 624 (m), 593 (s), 568 (m), 488 (w), [V=O] 982 (vs). UV-Vis (DMSO): 324, $515 \mathrm{~nm},(\mathrm{MeCN}): 253,277,507 \mathrm{~nm},(\mathrm{EtOH}): 272,324,511 \mathrm{~nm}$.

\section{$\left[\mathrm{VO}\left(\mathrm{L}_{4}\right)(\right.$ phen $\left.)\right] \cdot 2 \mathrm{H}_{2} \mathrm{O}, 5$}

The bald $(0.352 \mathrm{~g}, 1.5 \mathrm{mmol})$ and the 4-chlorobenzhydrazide $(0.254 \mathrm{~g}, 1.5 \mathrm{mmol})$ and $\mathrm{EtOH}(50 \mathrm{ml})$ were refluxed for $10 \mathrm{~min}$ utes under Ar. Then [VO(acac) $)_{2}$ ( $\left.0.394 \mathrm{~g}, 1.5 \mathrm{mmol}\right)$ was added. The immediate change of solution colour to dark green and then brown was observed. The mixture was refluxed for 20 minutes and 1,10-phenanthroline $(0.276 \mathrm{~g}, 1.5 \mathrm{mmol})$, in $10 \mathrm{ml}$ of EtOH, was added. The solution turns to blooded-red. The solution was left for crystallization. The formed crystals were filtered off, washed with EtOH and dried in air. Yield: 0,183 g, $18 \%$. MW = 668.08. Anal. Calcd. for $\mathrm{C}_{34} \mathrm{H}_{37} \mathrm{ClN}_{4} \mathrm{O}_{5} \mathrm{~V}: \mathrm{C}, 61.13 ; \mathrm{H}, 5.58$; N, $8.39 \%$. Found: C, 60.67; H, 5.24; N, 7.50\%. The complex is paramagnetic, $\mu=1.48 \mu_{\mathrm{B}}$. FT-IR ( $\left.\mathrm{KBr}, \mathrm{cm}^{-1}\right): 3465$ (s,br), 2945 (vs), 2863 (w), 1646 (w), 1608 (vs), 1585 (s), 1519 (s), 1490 (s), 1464 (w), 1428 (s), 1386 (m), 1364 (s), 1273 (w), 1252 (m), 1197 (w), 1169 (m), 1142 (w), 1089 (m), 1016 (w), 913 (w), 845 (s), 781 (w), 726 (s), 643 (w), 588 (w), 554 (w), 456 (w), [V=O] 966 (s). UV-Vis (DMSO): 331, $418 \mathrm{~nm},(\mathrm{MeCN}): 263,332,421 \mathrm{~nm},(\mathrm{EtOH}): 230$, 265, 333, $429 \mathrm{~nm}$.

\section{[VO(L $\left.\left.\mathrm{L}_{5}\right)(\mathrm{EtO})\right], 6$}

The bald (0.352 g, $1.5 \mathrm{mmol})$ and the 3-hydroxy-2-naphthoic acid hydrazide $(0.303 \mathrm{~g}, 1.5 \mathrm{mmol})$ were dissolved in $80 \mathrm{ml}$ of EtOH under Ar flow on a magnetic stirrer. The mixture was refluxed for 35 minutes with constant stirring and the temperature was raised to $100^{\circ} \mathrm{C}$. Then $\operatorname{VOSO}_{4} \mathrm{aq}(0.333 \mathrm{~g}, 1.5 \mathrm{mmol})$ and $15 \mathrm{ml}$ of $\mathrm{EtOH}$ were added and the mixture was refluxed for 180 minutes. After that, the volume of the reaction mixture was concentrated to final volume of ca. $20 \mathrm{ml}$ and cooled to the room temperature. The black powder started to precipitate from dark brown solution. The precipitate was filtered off, washed with ethanol and dried in air. Yield: $0.614 \mathrm{~g}, 77 \% . \mathrm{MW}=528.51$. Anal. Calcd. for $\mathrm{C}_{28} \mathrm{H}_{33} \mathrm{~N}_{2} \mathrm{O}_{5} \mathrm{~V}$ : C, 63.63; H, 6.29; N, 5.30\%. Found: C, 63.85; H, $6.23 ; \mathrm{N}, 5.32 \%$. The complex is diamagnetic. FT-IR $\left(\mathrm{KBr}, \mathrm{cm}^{-1}\right)$ : 3465 (w,br), 2963 (vs), 2863 (w), 1642 (s), 1602 (s), 1575 (m), 1554 (s), 1523 (vs), 1470 (s), 1431 (w), 1390 (w), 1363 (m), 1342 (m), 1301 (s), 1270 (w), 1242 (m), 1215 (m), 1181 (m), 1147 (m), 1091 (m), 1053 (vs), 997 (vs), 929 (m), 904 (m), 873 (m), 854 (m), 756 (m), 747 (m), 707 (w), 656 (w), 642 (m), 619 (m), $569(\mathrm{w}), 552(\mathrm{w})$, 473 (w), [V=O] 951 (w). UV-Vis (DMSO): 334, $423 \mathrm{~nm},(\mathrm{MeCN})$ : 226, 261, 326, $415 \mathrm{~nm}$, (EtOH): 226, 269, 318, $417 \mathrm{~nm}$.

\section{[VO $\left.\left(\mathrm{L}_{6}\right) \mathrm{H}_{2} \mathrm{O}\right], 7$}

a) The bald $(0.469 \mathrm{~g}, 2.0 \mathrm{mmol})$ and the nicotinic hydrazide $(0.274 \mathrm{~g}, 2.0 \mathrm{mmol})$ in $40 \mathrm{ml}$ of EtOH were refluxed for 15 
minutes under Ar. Then the $\mathrm{VOSO}_{4} \mathrm{aq}(0.442 \mathrm{~g}, 2.9 \mathrm{mmol})$ was added. The reflux was continued for 25 minutes under Ar. The red compound was filtered off, washed several times with ethanol and dried in air. Yield: $0.134 \mathrm{~g}, 15 \%$. MW $=436.4$. Anal. Calcd for $\mathrm{C}_{21} \mathrm{H}_{27} \mathrm{~N}_{3} \mathrm{O}_{4} \mathrm{~V}$ : C, 57.80; H, 6.24; N, $9.63 \%$. Found: C, 57.28; H, 5.84; N, $9.53 \%$. The complex is paramagnetic, $\mu=1.20 \mu_{\mathrm{B}}$.

b) The bald $(0.703 \mathrm{~g}, 3.0 \mathrm{mmol})$ and the nicotinic hydrazide $(0.411 \mathrm{~g}, 3.0 \mathrm{mmol})$ in $50 \mathrm{ml}$ of EtOH were refluxed for 14 minutes under Ar. Then the $\left[\mathrm{VO}(\mathrm{acac})_{2}\right](0.795 \mathrm{~g}, 3.0 \mathrm{mmol})$ was added. The reflux was continued for 48 minutes under Ar. The brown compound was filtered off, washed several times with ethanol and dried in room temperature. Yield: $0.262 \mathrm{~g}, 20 \%$. $\mathrm{MW}=436.4$. Anal. Calc. for $\mathrm{C}_{21} \mathrm{H}_{27} \mathrm{~N}_{3} \mathrm{O}_{4} \mathrm{~V}: \mathrm{C}$, 57.80; H, 6.24; N, 9.63 \%. Found: C, 57.22; H, 5.72; N, 10.02 $\%$. The complex is paramagnetic, $\mu=1.20 \mu_{\mathrm{B}}$. FT-IR (KBr, $\mathrm{cm}^{-1}$ ): 3435 (w,br), 2951 (vs), 2863 (w), 1615 (vs), 1533 (s), 1482 (w), 1463 (w), 1433 (m), 1388 (w), 1362 (s), 1299 (w), 1274 (w), 1251 (m), 1198 (m), 1177 (m), 1060 (w), 922 (w), 880 (s), $838(\mathrm{w}), 779(\mathrm{w}), 756(\mathrm{w}), 725(\mathrm{~m}), 695(\mathrm{w}), 549(\mathrm{w}), 480(\mathrm{w})$, [V=O] 998 (w). UV-Vis (DMSO): 332, $420 \mathrm{~nm},(\mathrm{EtOH}): 259$, $337,457 \mathrm{~nm}$.

\section{[VO(L $\left.\left.\mathrm{L}_{6}\right)(\mathrm{EtO})(\mathrm{EtOH})\right], 8$}

The bald $(0.469 \mathrm{~g}, 2.0 \mathrm{mmol})$ and the nicotinic hydrazide $(0.274$ $\mathrm{g}, 2.0 \mathrm{mmol}$ ) in $60 \mathrm{ml}$ of EtOH were refluxed for 15 minutes under Ar. Then the $\mathrm{VOSO}_{4}$ aq $(0.442 \mathrm{~g}, 2.9 \mathrm{mmol})$ was added. The reflux was continued for 90 minutes under Ar. The mixture was left for crystallization. After one day the brown crystals precipitated and crystals were filtered off, washed several times with ethanol and dried in room temperature Yield: $0.400 \mathrm{~g}, 39 \%$. $\mathrm{MW}=$ 509.5. Anal. Calcd for $\mathrm{C}_{25} \mathrm{H}_{36} \mathrm{~N}_{3} \mathrm{O}_{5} \mathrm{~V}: \mathrm{C}, 58.93 ; \mathrm{H}, 7.12$; $\mathrm{N}, 8.25 \%$. Found: C, 58.40; H, 6.97; N, $8.16 \%$. The complex is diamagnetic. FT-IR (KBr, cm-1): 3435 (w,br), 3104 (w,br), 2963 (vs), 2856 (m), 1610 (vs), 1583 (m), 1555 (s), 1518 (s), 1466 (w), 1434 (s), 1407 (m), 1379 (s), 1362 (s), 1348 (s), 1273 (m), 1251 (m), 1209 (w), 1181 (m), 1149 (w), 1088 (s), 1052 (vs), 915 (s), 876 (w), 848 (m), $770(\mathrm{w}), 755$ (w), 720 (m), $702(\mathrm{w}), 644(\mathrm{~m}), 620(\mathrm{w}), 593$ (m), 563 (m) 480 (w), [V=O] 976 (vs). UV-Vis (DMSO): 331, 422 $\mathrm{nm},(\mathrm{MeCN}): 241,330,417 \mathrm{~nm},(\mathrm{EtOH}): 333,419 \mathrm{~nm}$.

\section{[VO(L6)(phen)].5H2O, 9}

The bald ( $0.351 \mathrm{~g}, 1.5 \mathrm{mmol})$ and the nicotinic hydrazide $(0.206$ $\mathrm{g}, 1.5 \mathrm{mmol}$ ) in $40 \mathrm{ml} \mathrm{EtOH}$ were refluxed for 10 minutes under Ar. Then the $\mathrm{VOSO}_{4}$ aq $(0.253 \mathrm{~g}, 1.4 \mathrm{mmol})$ in $5 \mathrm{ml}$ of $\mathrm{H}_{2} \mathrm{O}$ was added. The reflux was continued for 10 minutes under Ar. The 1,10-phenanthroline $(0.270 \mathrm{~g}, 1.5 \mathrm{mmol})$ was added. The solution was evaporated and the brown compound was obtained. Yield: 0.796 g, $77 \%$. MW = 688.67. Anal. Calcd. for $\mathrm{C}_{33} \mathrm{H}_{43} \mathrm{~N}_{5} \mathrm{O}_{8} \mathrm{~V}: \mathrm{C}$, 57.55; H, 6.29; N, 10.17 \%. Found: C, 57.76; H, 5.51; N, $9.86 \%$. The complex is paramagnetic, $\mu=1.34 \mu_{\mathrm{B}}$. FT-IR $\left(\mathrm{KBr}, \mathrm{cm}^{-1}\right)$ : 3441 (w,br), 3064 (w), 2951 (vs), 2869 (w), 1683 (m), 1607 (vs),
1536 (vs), 1464 (m), 1429 (vs), 1388 (w), 1363 (s), 1311 (w), 1284 (w), 1249 (w), 1232 (w), 1199 (w), 1174 (s), 1106 (w), 1027 (s), 845 (s), $784(\mathrm{w}), 770(\mathrm{w}), 727$ (vs), 644 (w), 624 (w), $580(\mathrm{~m}), 545$ (w), 481 (w), [V=O] 962 (s). UV-Vis (DMSO): 334, $428 \mathrm{~nm},(\mathrm{MeCN})$ : 226, 287, 342, $442 \mathrm{~nm}$, (EtOH): 226, 268, 337, $445 \mathrm{~nm}$.

\section{$\left[\mathrm{VO}\left(\mathrm{L}_{2}\right)(\right.$ maltol $\left.)\right], 10$ and $\left[\mathrm{VO}\left(\mathrm{L}_{3}\right)(\mathrm{bpy})\right] \cdot \mathrm{MeOH}, 11$}

The syntheses and physicochemical characterization of the $\mathbf{1 0}$ and $\mathbf{1 1}$ complexes were described and discussed in [28]. In this paper we present the pharmacological activity of these compounds.

\section{Crystallographic data collection and structure refinement}

Crystal data, data collection and structure refinement details are summarized in Table 2. Positions of all of non-hydrogen atoms were determined by direct methods using SHELXT2017 [29]. All non-hydrogen atoms were refined anisotropically using weighted full-matrix least-squares on $\mathrm{F}^{2}$. Refinement and further calculations were carried out using SHELXL2017 [30]. All hydrogen atoms joined to carbon atoms were positioned with an idealized geometries and refined using a riding model with $\mathrm{U}_{\text {iso }}(\mathrm{H})$ fixed at $1.5 \mathrm{U}_{\text {eq }}$ of $\mathrm{C}$ for methyl groups and $1.2 \mathrm{U}_{\text {eq }}$ of $\mathrm{C}$ for other groups.

\section{Results and Discussion}

The Schiff base formed in situ in EtOH solution reacts with the appropriate vanadium substrate, yielding the complexes 1-9. We used two different V(IV) sources - $\left[\mathrm{VO}(\mathrm{acac})_{2}\right]$ or $\mathrm{VOSO}_{4} \mathrm{aq}$ and it was found that the product formula does not depend on substrate, as shown in synthesis of 7. But in some cases, the solubility of $\mathrm{VOSO}_{4}$ is low in EtOH, resulting in formation of undissolved substrate, which can contaminates the product. Thus the time of reflux had to be carefully controlled. As the ligand $\mathrm{L}_{\mathrm{n}}(\mathrm{n}=1-6)$ is tridentate, the complex needs a co-ligand to fill the coordination sphere. When additional co-ligand is not added, vanadium coordinates or solvent molecule (as in case of $\mathbf{2}$, 6-8) or ligand $\mathrm{L}_{\mathrm{n}}$ (complex 3) or its components (complex 4). The coordination of solvent molecule results in redox instability of the product and the oxidation to $\mathrm{V}(\mathrm{V})$ in most cases is observed (complexes 2, 6, 8). Also maltol as co-ligand does not stabilize the +4 oxidation state (complex 1). When phen was used (complexes $\mathbf{5}$ and 9), the complexes are fairly stable in air and can be kept in air for long period (within 9 years after preparation only a small decrease in magnetic moment is observed).

\section{Crystal structure}

A single crystal X-ray study reveals that the asymmetric part of the unit cell of the complex, $\left[\mathrm{VO}\left(\mathrm{L}_{6}\right)(\mathrm{EtO})(\mathrm{EtOH})\right](8)$, where $\mathrm{L}_{6}=\mathrm{N}^{\prime}$-[(E)-(2-hydroxy-3,5-ditertbuthylphenyl)metylidene $]$ pyridine-3-carbohydrazide consists of one crystallographical- 
Table 2. Experimental details for complex 8.

\begin{tabular}{|c|c|}
\hline \multicolumn{2}{|l|}{ Crystal data } \\
\hline Chemical formula & {$\left[\mathrm{VO}\left(\mathrm{C}_{21} \mathrm{H}_{25} \mathrm{~N}_{3} \mathrm{O}_{2}\right)\left(\mathrm{C}_{2} \mathrm{H}_{5} \mathrm{O}\right)\left(\mathrm{C}_{2} \mathrm{H}_{5} \mathrm{OH}\right)\right]$} \\
\hline $\mathrm{M}_{\mathrm{r}}$ & 509.51 \\
\hline Crystal system, space group & Monoclinic, $P 2_{l}$ \\
\hline Temperature $(\mathrm{K})$ & $293(2)$ \\
\hline$a, b, c$ & 8.459(2), 15.091(4), 10.552(3) \\
\hline$b\left(^{\circ}\right)$ & 93.204(1) \\
\hline $\mathrm{V}\left(\AA^{3}\right)$ & $1344.91(6)$ \\
\hline Z & 2 \\
\hline Radiattion type & Mo $K \alpha$ \\
\hline$\mu\left(\mathrm{mm}^{-1}\right)$ & 0.406 \\
\hline Crystal size (mm) & $0.46 \times 0.23 \times 0.04$ \\
\hline \multicolumn{2}{|l|}{ Data collection } \\
\hline Diffractometer & Nonius Kappa CCD \\
\hline Absorption correction & Semi-empirical from equivalents \\
\hline$T_{\min }, T_{\max }$ & $0.8356,0.984$ \\
\hline $\begin{array}{l}\text { No. of measured, independent and } \\
\text { observed }[I>2 \sigma(I)] \text { reflections }\end{array}$ & $23447,6092,5571$ \\
\hline$R_{\text {int }}$ & 0.0492 \\
\hline$(\sin \theta / \lambda)_{\max }\left(\AA^{-1}\right)$ & 0.649 \\
\hline \multicolumn{2}{|l|}{ Refinement } \\
\hline$R\left[F^{2}>2 \sigma\left(F^{2}\right)\right], w R\left(F^{2}\right), \mathrm{S}$ & $0.0371,0.0908,1.026$ \\
\hline No. of reflections & 6092 \\
\hline No. of parameters & 346 \\
\hline No. of restraints & 2 \\
\hline $\mathrm{H}$-atom treatment & $\mathrm{H}$ atoms treated by a mixture of independent and constrained refinement \\
\hline$\Delta \rho_{\max }, \Delta \rho_{\min }\left(\mathrm{e} \AA^{-3}\right)$ & $0.386-0.258$ \\
\hline
\end{tabular}

ly independent $\mathrm{V}^{\mathrm{V}}$ ion surrounded by oxo ligand, one $\mathrm{L}_{6}$ ligand molecule, one ethoxy ligand (EtO-) and one ethanol molecule.

The asymmetric unit of the complex with the adopted atomic numbering scheme is shown in Fig. 1. The crystallographic data and detailed information on the structure solution and refinement for $\mathbf{8}$ are given in Table 2. Selected bond distances and bond angles are listed in Table 3 .

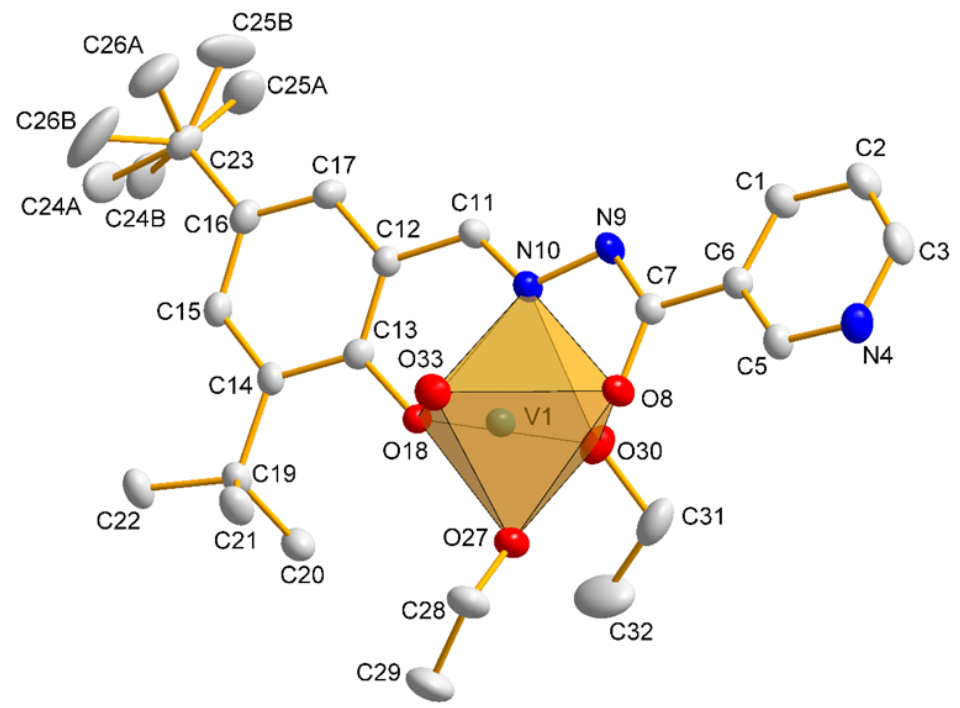

Figure 1. A view of the coordination environment of the $\mathrm{VV}$ atom in $\mathbf{8} . \mathrm{H}$ atoms have been omitted for clarity. Displacement ellipsoids are drawn at the $30 \%$ probability level. The figure was prepared using DIAMOND [31] 
Table 3. Selected bond lengths $[\AA]$ and angles $\left[{ }^{\circ}\right]$ for $\mathbf{8}$.

\begin{tabular}{|c|c|}
\hline V1-O33 & $1.589(2)$ \\
\hline V1-O27 & $1.776(2)$ \\
\hline V1-O18 & $1.845(2)$ \\
\hline V1-O8 & $1.956(2)$ \\
\hline V1-N10 & $2.113(2)$ \\
\hline V1-O30 & $2.336(2)$ \\
\hline C7-N9 & $1.300(4)$ \\
\hline $\mathrm{C} 7-\mathrm{O} 8$ & $1.302(4)$ \\
\hline N9-N10 & $1.399(3)$ \\
\hline N10-C11 & $1.285(4)$ \\
\hline O33-V1-O27 & $103.20(12)$ \\
\hline O33-V1-O18 & $97.89(11)$ \\
\hline O27-V1-O18 & 101.32(9) \\
\hline O33-V1-O8 & $100.02(11)$ \\
\hline $\mathrm{O} 27-\mathrm{V} 1-\mathrm{O} 8$ & $95.38(10)$ \\
\hline O18-V1-O8 & $151.97(10)$ \\
\hline O33-V1-N10 & $93.85(11)$ \\
\hline O27-V1-N10 & $161.56(11)$ \\
\hline O18-V1-N10 & $82.97(9)$ \\
\hline O8-V1-N10 & $74.49(9)$ \\
\hline O33-V1-O30 & 171.31(11) \\
\hline O27-V1-O30 & $85.40(10)$ \\
\hline O18-V1-O30 & 78.93(9) \\
\hline O8-V1-O30 & $80.16(9)$ \\
\hline N10-V1-O30 & $77.78(9)$ \\
\hline
\end{tabular}

In the structure surroundings of the central $\mathrm{V}^{\mathrm{V}}$ form a distorted octahedral $\mathrm{O}_{5} \mathrm{~N}$ conformation. The equatorial plane defined by atoms $\mathrm{O} 18, \mathrm{O} 8$ and $\mathrm{N} 10$ of the fully deprotonated tridentate hydrazone ligand $\left(\mathrm{L}_{6}\right)$ and $\mathrm{O} 27$ of ethoxy group (r.m.s. $=0.0183$ $\AA$ ). The oxo $\mathrm{O} 33$ atom and atom $\mathrm{O} 30$ of the ethanol molecule occupy the apical sites of the octahedron with a trans angle of $171.3(1)^{\circ}$. The central vanadium atom is above the basal plane by 0.301 (1) $\AA$ and is directed towards the oxo O33 atom. As a consequence, the $\mathrm{O} 33$ ligand is significantly closer to the $\mathrm{V}^{\mathrm{V}}$ cation than the other groups, and for the complex the $\mathrm{V}-\mathrm{O}_{\text {oxo }}$ distance is equal to $1.589(2) \AA$, which is in agreement with data for other pentacoordinate oxovanadium(V) compounds [32-34]. In the complex the four $\mathrm{V}-\mathrm{O}$ bond lengths are unequal, with the $\mathrm{V}=\mathrm{O}$ bond being the shortest and the $\mathrm{V}-\mathrm{O} 30=2.336(2) \AA$ (enolate) bond the longest. The magnitude, 2.113(2) $\AA$, of the V1-N10 bond indicates a low affinity between the imine $\mathrm{N}$ atom and the central atom in neutral oxidovanadium $(\mathrm{V})$ complexes. The $\mathrm{V}-\mathrm{O}$ bond lengths follow the order: $\mathrm{V}-\mathrm{O} 33$ oxo $>\mathrm{V}-\mathrm{O} 27$ ethoxo $>\mathrm{V}-$ O18phenoxo $>$ V-O8alkoxo $>$ O30enolate. These data indicate stronger binding of the alkoxo group compared to the enolate oxygen atoms. Analysis of the crystal structure of $\mathbf{8}$ at the supramolecular level reveals that the complex molecules are held together by typical hydrogen and two $\pi \cdots \pi$ interactions (Fig. 2), which are summarized in Tables 4 and 5, respectively. All these interactions are responsible for the self-assembly of the complex molecules and stabilization of the 3D structure.

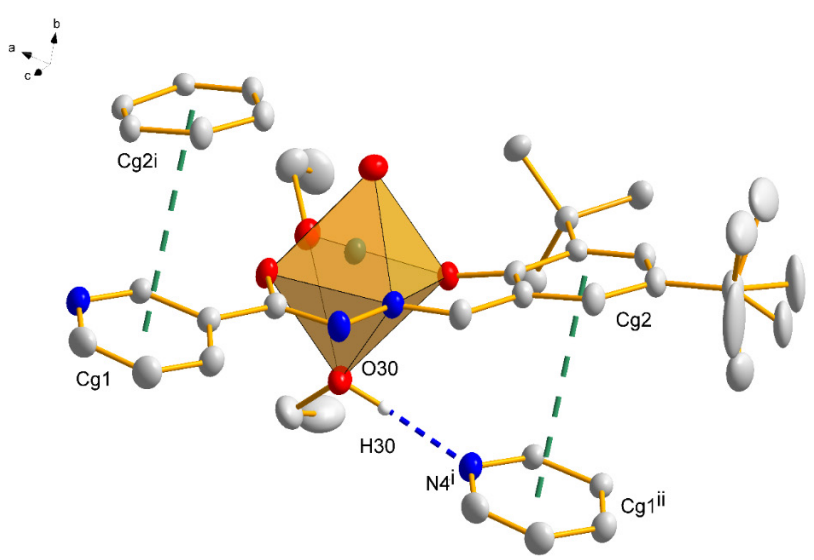

Figure 2. The 3D supramolecular network of 8 formed through $\mathrm{O}-\mathrm{H} \cdots \mathrm{N}$ and $\pi \cdots \pi$ interactions. [Symmetry codes: (i) $\mathrm{x}-1, \mathrm{y}, \mathrm{z}$; (ii) $\mathrm{x}+1, \mathrm{y}, \mathrm{z}$ ]. The figure was prepared using DIAMOND [31]

Table 4. Hydrogen-bond geometry $\left(\AA,^{\circ}\right)$

\begin{tabular}{|c|c|c|c|c|}
\hline D-H...A & $d(D-H)$ & $\mathrm{d}(\mathrm{H} . . . \mathrm{A})$ & d(D...A) & $<(\mathrm{DHA})$ \\
\hline $\mathrm{O} 30-\mathrm{H} 30 \cdots \mathrm{N} 4^{\mathrm{i}}$ & $0.94(3)$ & $1.90(3)$ & $2.834(4)$ & $169(5)$ \\
\hline
\end{tabular}

Symmetry codes: (i) $x-1, y, z$

Table 5. $\pi \cdots \pi$ interaction geometry in $\mathbf{8}(\AA)$. Cg1: N(4)-C(3)-C(2)-C(1)-C(6)-C(5), Cg2: C(12)-C(13)-C(14)-C(15)-C(16)-C(17)

\begin{tabular}{lll}
\hline & $\mathrm{Cg} \cdots \mathrm{Cg}$ & Slippage \\
\hline $\mathrm{Cg} 1 \cdots \mathrm{Cg} 2^{\mathrm{i}}$ & $3.9850(1)$ & 1.787 \\
$\mathrm{Cg} 2 \cdots \mathrm{Cg} 1^{\mathrm{ii}}$ & $3.9850(1)$ & 1.477 \\
\hline
\end{tabular}

Symmetry codes: (i) $\mathrm{x}-1, \mathrm{y}, \mathrm{z}$; (ii) $\mathrm{x}+1, \mathrm{y}, \mathrm{z}$

\section{UV-Vis spectra}

The UV-Vis spectral data are collected in Synthesis for each complex. As the solubility of the complexes is poor, only inter ligand transitions are observed, the less energetic one is connected with the formation of imine group within Schiff base. The more interesting thus are the spectra in solid state, in which, due to the technique used, the low intensity $d$ - $d$ transitions can be also observed. The reflectance spectra, after Kubelka-Munk transformation, are presented separately for diamagnetic (Fig. 3) and paramagnetic (Fig. 4) complexes. The presented spectra are very similar to that in solution, for paramagnetic complexes the $d$ - $d$ bands are better visible, as in solution these forbidden transitions have a very low intensity, compared to allowed CT ones. 


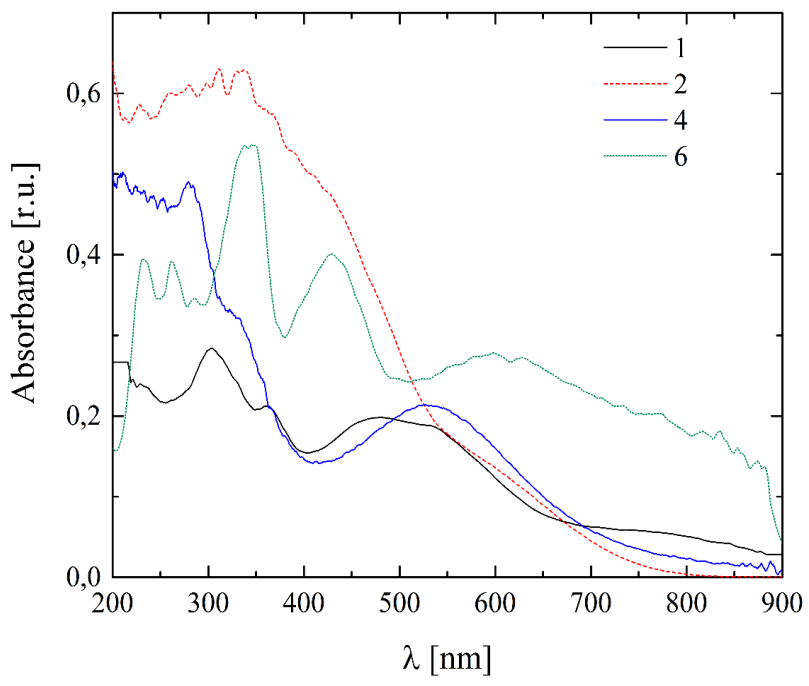

Figure 3. Reflectance spectra (after Kubelka-Munk transformation) of diamagnetic complexes 1, 2, 4 and 6. $\mathrm{BaSO}_{4}$ as internal white standard

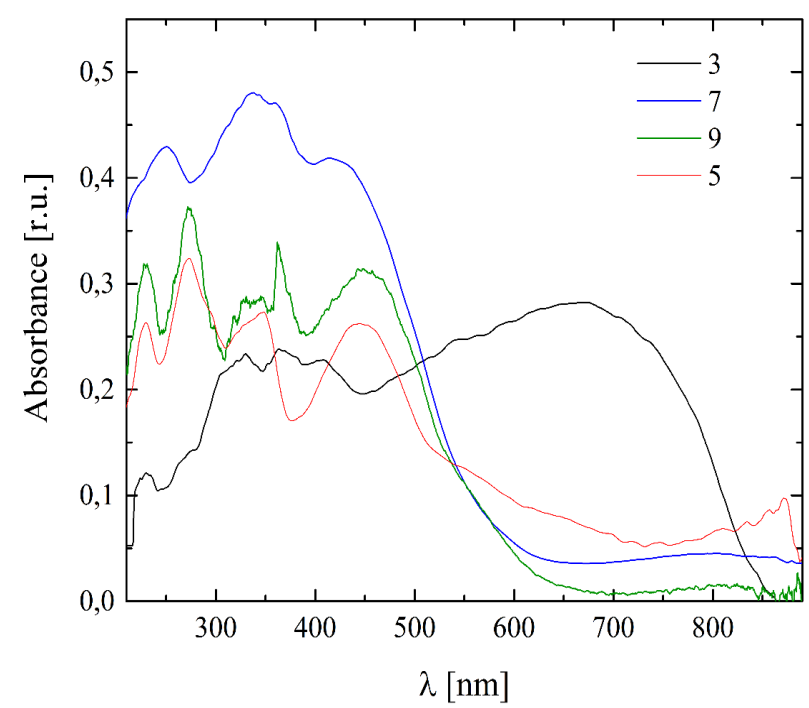

Figure 4. Reflectance spectra (after Kubelka-Munk transformation) of paramagnetic complexes $\mathbf{3}, \mathbf{5}, \mathbf{7}$ and $\mathbf{9} . \mathrm{BaSO}_{4}$ as internal white standard

\section{Magnetic measurements}

To find the exact oxidation state of vanadium, the magnetic susceptibility measurements were performed using a magnetic Ewan's balance. The calculated magnetic moments are presented in the Experimental part. Complexes 1, 2, 4, 6 and 8 were diamagnetic, while the magnetic moment of complexes 3, 5, 7 and 9 indicate on V(IV) with $d^{l}$ configuration. The EPR spectra of complexes, were measured both at room and at liquid nitrogen temperature for solid samples and are in agreement with the magnetic susceptibility data. The EPR spectra at room temperature show g parameter equal to 1.978 (3), typical for vanadium(IV). The absence of hyperfine structure indicates on V-V interaction in condensed phase, both at room and at liquid nitrogen temperature.

\section{Thermogravimetry}

Thermal decomposition processes for complexes $\mathbf{3}$ and $\mathbf{9}$ are presented in Fig. 5, while numerical data are collected in Table 6.

The decomposition of complex $\mathbf{3}$ starts early, the final mass loss is $90.17 \%$, calculated for EtOH and ligand release is 92.09 , these both values fit quite well including oxidation processes and formation of $\mathrm{V}_{2} \mathrm{O}_{5}$ as a final product. For complex 9 several, not well resolved, decomposition processes can be seen in Fig. 5 . The raft estimations gave in Table 6 show that water is released in two separated steps and then phen ligand is released. As the plateaus are not well reached (see Fig. 5) the mass loss can only be estimated (basing on SDTA plots). The next step is two-step decomposition of ligand L, probably, as indicated in Table 6, first hydrazide and then in second step aldehyde part of the ligand are released. Such a stepwise decomposition of Schiff base ligand was observed earlier by us $[9,10,26]$. The total mass loss is $96.90 \%$, calculated $93.03 \%$.
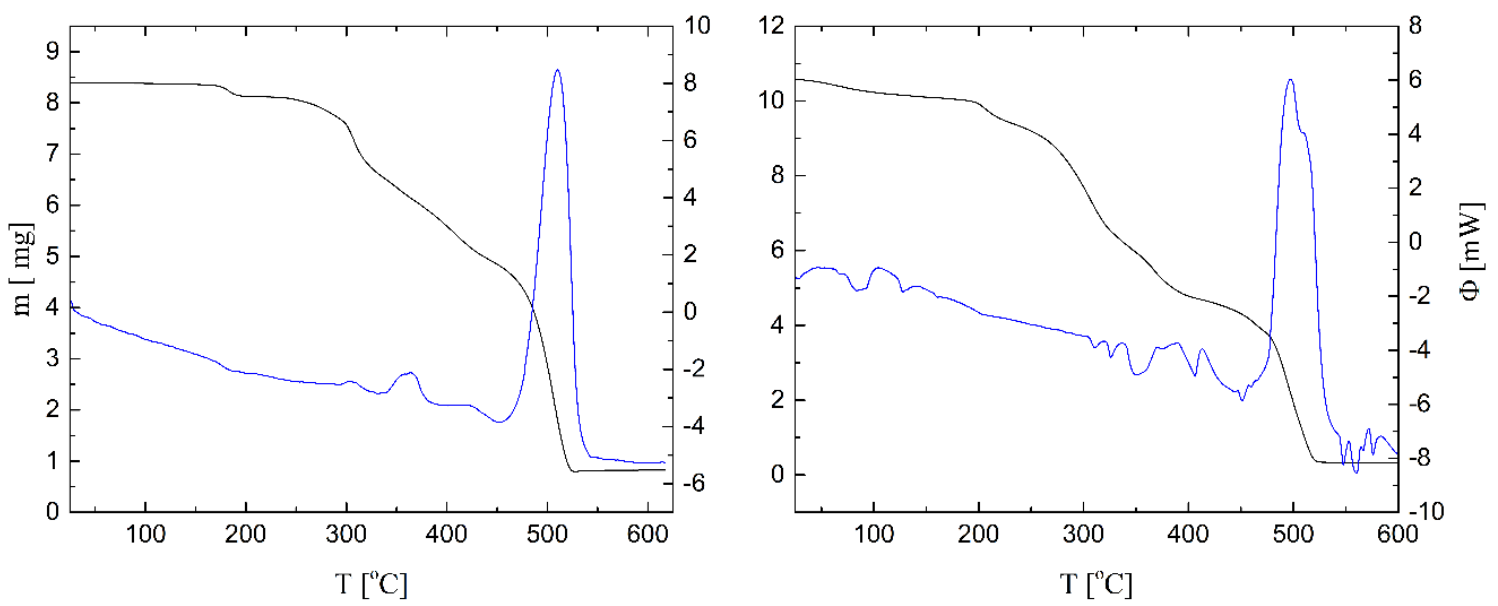

Figure 5. TG (left axis) and SDTA (right axis) curves for 3 (left) and $\mathbf{9}$ (right). Scan speed $10^{\circ} / \mathrm{min}$, air 
Table 6. The TG and SDTA data for complexes 3 and $\mathbf{9}$. Scan speed $10^{\circ} / \mathrm{min}$.

\begin{tabular}{|c|c|c|c|c|c|}
\hline Complex & $\mathbf{m}[\mathbf{m g}]$ & $\mathbf{T}_{\max }\left[{ }^{\circ} \mathbf{C}\right]$ (SDTA) & $\Delta \mathrm{m}_{\text {exp }}[\%]$ & $\Delta \mathbf{m}_{\text {calc }}[\%]$ & Attributed to \\
\hline \multirow[t]{7}{*}{3} & 8.3938 & & & & \\
\hline & 8.1229 & 184 (endo) & 3.23 & & \\
\hline & & 304 (ехо) & & & \\
\hline & & $358 \mathrm{sh}$ (exo) & & & \\
\hline & & 363 (exo) & & & \\
\hline & & 419sh (exo) & & & \\
\hline & 0.8251 & 510 (ехо) & 86.94 & 92.09 & $2 \mathrm{~L}+\mathrm{EtOH}$ \\
\hline \multirow[t]{9}{*}{9} & 10.5750 & & & & \\
\hline & & 85 (endo) & & & \\
\hline & 10.0699 & 127 (endo) & 4.78 & 5.23 & $2 \mathrm{H}_{2} \mathrm{O}$ \\
\hline & 9.3849 & 311 (endo) & 6.48 & 7.84 & $3 \mathrm{H}_{2} \mathrm{O}$ \\
\hline & 6.1648 & 326 (endo) & 30.45 & 26.17 & phen \\
\hline & & 349 (endo) & & & \\
\hline & 4.6887 & 406 (endo) & 13.96 & 19,91 & L(hydrazide) ${ }^{\mathrm{a}}$ \\
\hline & & 497 (exo) & & & \\
\hline & 0.3272 & $510 \operatorname{sh}(\mathrm{exo})$ & 41.24 & 33,88 & L(aldehyde) ${ }^{b}$ \\
\hline
\end{tabular}

* - rest of the peaks, shown in Fig. 5 were not listed, a $\Delta \mathrm{m}$ calculated for release of hydrazide part of the ligand, $\mathrm{b} \Delta \mathrm{m}$ calculated for release of the aldehyde from the ligand.

\section{Cyclic voltammetry}

Cyclic voltammograms for selected complexes are presented in Figs. 6 and 7. In general the presented data indicate on irreversible processes connected with the vanadium oxidation (at positive potentials), this is a typical behavior for vanadyl compounds. The reversible redox processes at negative potentials are observed for complexes with bidentate co-ligands $(\mathbf{1}, \mathbf{3}, \mathbf{4}$ and 5), as exemplified in Fig. 7. This behavior was found earlier by us for complexes with phen as a co-ligand, the $\mathrm{E}_{1 / 2}=-1.31$ $\mathrm{V}$ for 5 (with $E_{a} / E_{c}$ peak separation of $110 \mathrm{mV}$ at scan speed $100 \mathrm{mV} / \mathrm{s}$ ). Similar behavior shows the complex 1 with maltol as a co-ligand with $\mathrm{E}_{1 / 2}=-0.116 \mathrm{~V}$ and $\mathrm{E}_{\mathrm{a}} / \mathrm{E}_{\mathrm{c}}$ peak separation of $73 \mathrm{mV}$ (at scan speed $100 \mathrm{mV} / \mathrm{s}$ ), indicating on one electron
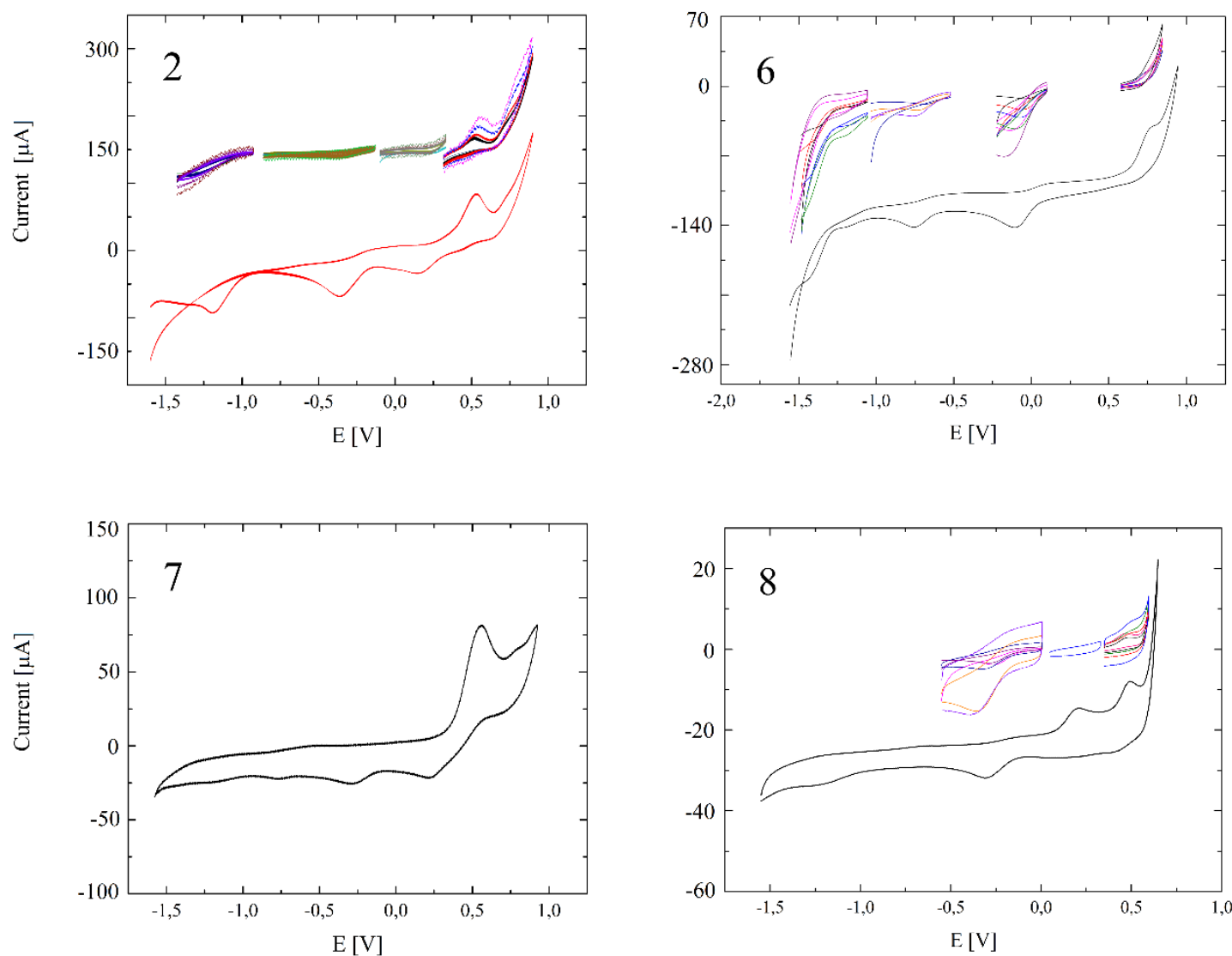

Figure 6. Cyclic voltammograms of complexes 2, 6, 7 and 8 in DMSO. Pt working and counting, $\mathrm{Ag} / \mathrm{AgCl}$ as reference electrodes. Potentials versus SHE. 0.1 $\mathrm{M} \mathrm{Bu}_{4} \mathrm{NPF}_{6}$, scan speed (full curve) $100 \mathrm{mV} / \mathrm{s}$, insets scan speeds from $20-1000 \mathrm{mV} / \mathrm{s}$ 

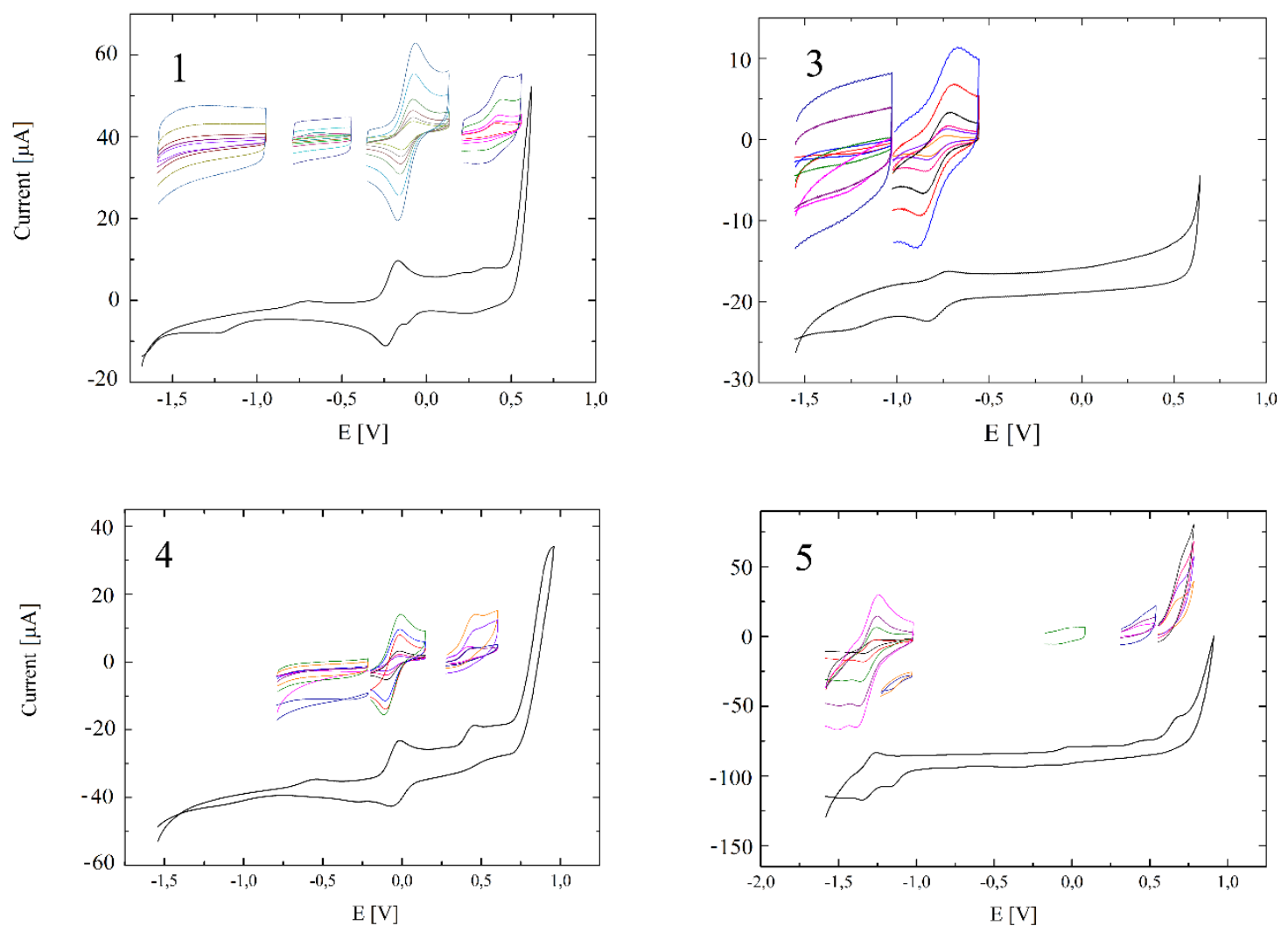

Figure 7. Cyclic voltammograms of complexes 1, 3, 4 and 5 in DMSO. Pt working and counting, $\mathrm{Ag} / \mathrm{AgCl}$ as reference electrodes. Potentials versus SHE. 0.1M Bu $\mathrm{NPF}_{6}$, scan speed (full curve) $100 \mathrm{mV} / \mathrm{s}$, insets scan speeds from $20-1000 \mathrm{mV} / \mathrm{s}$.

process. The independence of $\mathrm{E}_{1 / 2}, \mathrm{E}_{\mathrm{a}}$ and $\mathrm{E}_{\mathrm{c}}$ on scan speed and symmetry of peaks support the reversibility of the redox process. The electrochemical reversibility observed for complexes 3 and $\mathbf{4}$ are directly connected with bidentate co-ligand (bald for 4, and bidentate $L_{2}$ ligand in 3). The $E_{1 / 2}=-0.782 \mathrm{~V}\left(\mathrm{E}_{\mathrm{a}} / \mathrm{E}_{\mathrm{c}}\right.$ peak separation $130 \mathrm{mV})$ for 3 and $E_{1 / 2}=-0.059 \mathrm{~V}\left(\mathrm{E}_{\mathrm{a}} / \mathrm{E}_{\mathrm{c}}\right.$ peak separation $94 \mathrm{mV}$ ) at scan speed $100 \mathrm{mV} / \mathrm{s}$. For 4 the reversible process is connected with coordination of bald, much lower potential observed for 3 with the $\mathrm{L}_{2}$ ligand indicates that the hydrazide part (different in $\mathbf{3}$ and $\mathbf{4}$ ) stabilizes the aldehyde part of Schiff base. In case of ligand $\mathrm{L}_{2}$ (in complex 3 ) aromatic ring of hydrazide stabilizes the aldehyde part, while when aliphatic separator between aromatic ring and hydrazide part (as in ligand $\mathrm{L}_{3}$ ) is present, such a stabilization is not observed, and in 4 redox processes are less energetic.

\section{Complex stability in solution}

The admission of vanadium complexes in in vitro and in vivo studies complicates theirs solubility, stability on transfer through digestion system (with $\mathrm{pH}$ as low as 2.0) and transfer to the cell. Due to the almost insolubility in water of synthesized complexes, we were forced to use DMSO as a solvent in the mixture with water. DMSO is very popular in medicine as it helps in transfer of many substances through biological membranes. However, in in vitro studies, the main medium for cells is water (as solvents for all biological buffers and media). We firstly studied the stability of the complexes in pure DMSO, by measuring the UV-Vis spectra versus time. We have found, that the solutions of all 1-9 complexes are stable in DMSO. In DMSO- $\mathrm{H}_{2} \mathrm{O}$ $(20 \mu 1+3 \mathrm{ml}$, respectively) mixtures at native $\mathrm{pH}$ complexes are fairly stable and only small decomposition is observed (less than $10 \%$ of decomposition after $90 \mathrm{~min}$ ). At $\mathrm{pH}=2.00$ complexes 5 and 7 are stable, while others undergoes slow decomposition, still over $50 \%$ of initial complex amount remains after 90 minutes. All these facts indicate, that all studied complexes are stable enough to survive the conditions present in human digestion system. The sample spectra changes for complex $\mathbf{6}$ are presented in Fig. 8. 

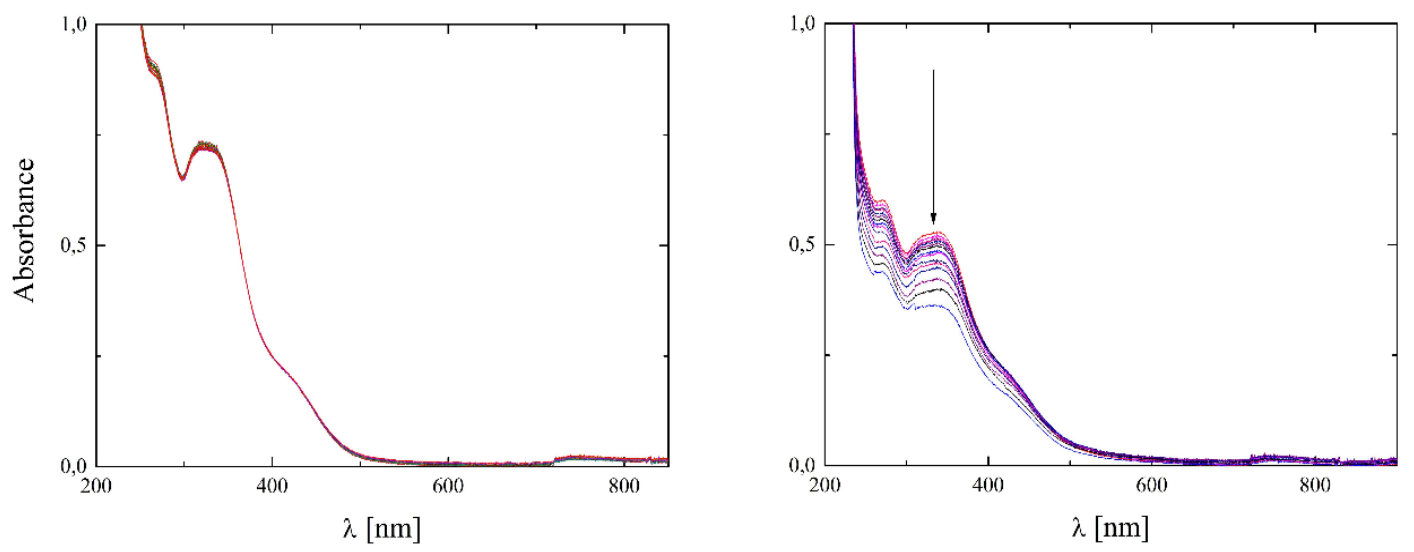

Figure 8. UV-Vis spectra of complex 6 in DMSO- $\mathrm{H}_{2} \mathrm{O}$ mixture $(20 \mu \mathrm{l}+3 \mathrm{ml}$ respectively) mixture at native $\mathrm{pH}$ (left) and at $\mathrm{pH}=2.00$ (right). $\mathrm{T}=37^{\circ} \mathrm{C}, \mathrm{d}=1 \mathrm{~cm}, 15$ spectra measured in $340 \mathrm{~s}$ intervals. The arrow shows direction of changes in spectra

\section{Biological activity of selected complexes}

All tested complexes $(\mathbf{2}, \mathbf{3}, \mathbf{5}, \mathbf{7}, \mathbf{9 - 1 1})$ as well as comparative compounds ( $\mathrm{VOSO}_{4}, \mathrm{BMOV}$ and suramin) were shown the inhibitory effect on human recombinant PTP1B at $100 \mu \mathrm{M}$ concentration $(\mathrm{P} \leq .001)$ as shown in Fig. 9. All complex showed a weaker degree of inhibition both to the inorganic vanadium reference compound and to the organic vanadium complex BMOV [bis(maltolato)oxovanadium(IV)] whose pharmacological activity has been extensively studied and which has been in phase III clinical trials. The compounds $\mathbf{5}$ and $\mathbf{9}$ have been shown a significantly more potent PTP1B inhibition ability than the other tested compounds and over twice higher inhibition than suramin.

The very important part in application of compounds is their cytotoxicity. The cytotoxicity of tested compounds on HepG2 hepatocytes is presented in Fig. 10. The results were normalized to the control (cells with solvent only), wherein the intensity of fluorescence was taken as 100\%. The complex $\mathbf{3}$ does not show

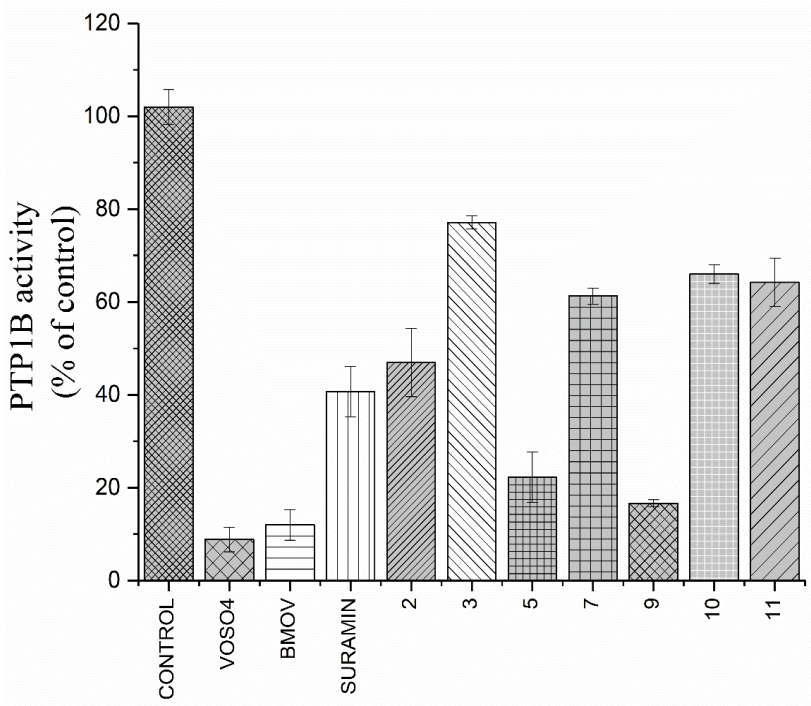

Figure 9. Inhibition of human PTP1B. Error bars: +/- SD. Statistically significant differences in comparison to control: $* * * \mathrm{p}=0.0001$ (for $\mathrm{VOSO}_{4}$, BMOV, suramin, 2, 5, 7, 9, 10, 11), *p $=0.01$ (for 3) significant cytotoxicity compared to control and to $\mathrm{VOSO}_{4}$ or $\mathrm{BMOV}$, while all other complexes possesses high cytotoxicity.

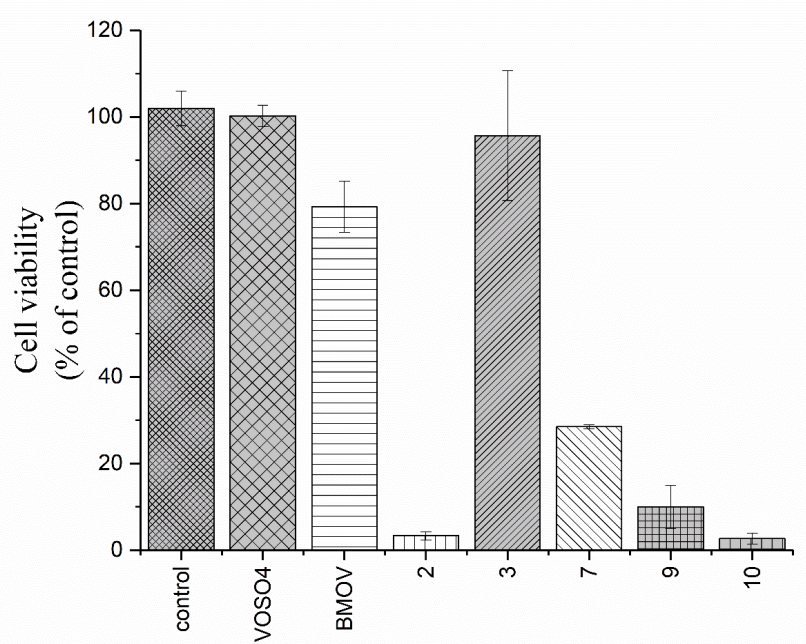

Figure 10. Cytotoxicity of tested compounds on HepG2 hepatocytes. Error bars: $+/-\mathrm{SD}$. Statistically significant differences in comparison to control: *** $\mathrm{p}=0.0001$ (for 2, 7,9 and 10)

\section{Conclusions}

Nine new complexes of vanadium with ONO donating Schiff hydrazido-hydrazones are described and characterized. All complexes contain the $\mathrm{V}=\mathrm{O}$ group. The bidentate co-ligands not only stabilize the V(IV) oxidation state, but also stabilize complexes in solution, even at $\mathrm{pH}$ 2.00. The stabilization at low $\mathrm{pH}$ is very important in vanadium applications as pharmaceuticals. In contrary to bidentate ligands, as in BMOV, coordination of tridentate ligand results in strong dependence of biological activity (cytotoxicity and inhibition of human PTP1B) on type of ligand used. This, together with complex stability, indicates that ONO ligand is not released during migration to the cells and the biological activity depends on ONO ligand composition and not only on presence of $\mathrm{VO}^{2+}$ anions. Further studies are in progress. 


\section{Acknowledgments}

This work was partly financed by the European Regional Development Fund under the Innovative Economy Programme 2007-2013 (WND POIG.01.03.01-174/09). The complexes are protected by the patent P.401493.

\section{References}

1. Rehder D. Implications of vanadium in technical applications and pharmaceutical issues. Inorganica Chimica Acta. 2017; 455:378-389.

2. Azza AA. Synthesis and spectroscopic studies on ternary bis-Schiff-base complexes having oxygen and/or nitrogen donors. Journal of Coordination Chemistry. 2006; 59:157-176.

3. Pessoa JC, Etcheverry S, Gambino D. Vanadium compounds in medicine. Coordination Chemistry Review. 2015; 301302:24-48.

4. Dhar DN, Taploo CL. Schiff-bases and their applications. Journal of Scientific and Industrial Research. 1982; 41:501-506.

5. Jia Y, Li J. Molecular Assembly of Schiff Base Interactions: Construction and Application. Chemical Review. 2015; 115:1597-1621.

6. Przybylski P, Huczynski A, Pyta K, Brzezinski B, Bartl F. Biological properties of Schiff bases and azo derivatives of phenols. Current Organic Chemistry. 2009; 13:124-148.

7. Ebrahimipour SY, Sheikhshoaie I, Kautz AC, Ameri M, Pasban-Alibadi F, Rudbari HA, Bruno G, Janiak Ch. Mono-and dioxido-vanadium (V) complexes of a tridentate ONO Schiff base ligand: Synthesis, spectral characterization, X-ray crystal structure, and anticancer activity. Polyhedron. 2015; 93:99-105.

8. Zamarin D. Vanadium: A Panacea for Resistance to Oncolytic Immunotherapy? Molecular Therapy. 2018; 26:9-12.

9. Zabierowski P, Szklarzewicz J, Gryboś R, Modryl B, Nitek W. Assemblies of salen-type oxidovanadium (IV) complexes: substituent effects and in vitro protein tyrosine phosphatase inhibition. Dalton Transactions. 2014; 43:17044-17053.

10. Gryboś R, Szklarzewicz J, Jurowska A, Hodorowicz M. Properties, structure and stability of V (IV) hydrazide Schiff base ligand complex. Journal of Molecular Structure. 2018;1171:880-887.

11. Ma L, Lu L, Zhu M, Wang Q, Gao F, Yuan C, Wu Y, Xing S, Fu X, Mei Y, Gao X. Dinuclear copper complexes of organic claw: potent inhibition of protein tyrosine phosphatases. Journal of Inorganic Biochemistry. 2011; 105:1138-1147.

12. Wang Q, Zhu M, Lu L, Yuan C, Xing S, Fu X. Potent inhibition of protein tyrosine phosphatases by quinquedentate binuclear copper complexes: synthesis, characterization and biological activities. Dalton Transactions. 2011; 40:1292612934.
13. Lu L, Zhu M. Protein tyrosine phosphatase inhibition by metals and metal complexes. Antioxidants and Redox Signaling. 2014; 20:2210-2224.

14. Thompson KH, Orvig C. Vanadium in diabetes: 100 years from Phase 0 to Phase I. Journal of Inorganic Biochemistry. 2006; 100:1925-1935.

15. Domingo JL, Gomez M, Sanchez DJ, Llobet JM, Keen CL. Toxicology of vanadium compounds in diabetic rats: the action of chelating agents on vanadium accumulation. Molecular and Cellular Biochemistry. 1995; 153:233-240.

16. Domingo JL. Vanadium and tungsten derivatives as antidiabetic agents. Biological Trace Element Research. 2002; 88:97-112.

17. Gruzewska K, Michno A, Pawelczyk T, Bielarczyk H. Essentiality and toxicity of vanadium supplements in health and pathology. Journal of Physiology and Pharmacology. 2014; 65:603-611.

18. Evangelou AM. Vanadium in cancer treatment. Critical Reviews in Oncology/Hematology. 2002; 42:249-265.

19. Llobet JM, Domingo JL. Acute toxicity of vanadium compounds in rats and mice. Toxicology Letters. 1984; 23:227-231.

20. Srivastava AK. Anti-diabetic and toxic effects of vanadium compounds. Molecular and Cellular Biochemistry. 2000; 206:177-182.

21. Reul BA, Amin SS, Buchet JP, Ongemba LN, Crans DC, Brichard SM. Br. Effects of vanadium complexes with organic ligands on glucose metabolism: a comparison study in diabetic rats. British Journal of Pharmacology. 1999; 126:467-477.

22. Fujimoto S, Fujii K, Yasui H, Matsushita R, Takada J, Sakurai $\mathrm{H}$. Long-term acting and orally active vanadyl-methylpicolinate complex with hypoglycemic activity in streptozotocin-induced diabetic rats. Journal of Clinical Biochemistry and Nutrition. 1997; 23:113-129.

23. Halevas E, Tsave O, Yavropoulou MP, Hatzidimitriou A, Yovos JG, Psycharis V, Gabriel C, Salifoglou A. Design, synthesis and characterization of novel binary V (V)-Schiff base materials linked with insulin-mimetic vanadium-induced differentiation of 3T3-L1 fibroblasts to adipocytes. Structure-function correlations at the molecular level. Journal of Inorganic Biochemistry. 2015; 147:99-115.

24. Sugiyama H, Matsugo S, Misu H, Takamura T, Kaneko S, Kanatani Y, Kaido M, Mihara C, Abeywardana N, Sakai A, Sato K, Miyashita Y, Kanamori K. Regulation of the physiological effects of peroxidovanadium (V) complexes by the electronic nature of ligands. Journal of Inorganic Biochemistry. 2013; 121:66-76.

25. Dümmling S, Eichhorn E, Schneider S, Speiser B, Würde M. Recycling of the Supporting Electrolyte Tetra(n-butyl)ammonium Hexafluorophosphate from Used Electrolyte Solutions. Current Separations. 1996; 5:53-56.

26. Gryboś R, Paciorek P, Szklarzewicz J, Matoga D, Zabierowski P, Kazek G. Novel vanadyl complexes of acetoacetanilide: 
Synthesis, characterization and inhibition of proteintyrosine phosphatase. Polyhedron. 2013;49:100-104.

27. Sutradhar M, Martins LM, Carabineiro SA, Guedes da Silva MFC, Buijnsters JG, Figueiredo JL, Pombeiro AJL. Oxidovanadium (V) Complexes Anchored on Carbon Materials as Catalysts for the Oxidation of 1-Phenylethanol. Chem.Cat. Chem. 2016;8:2254-2266.

28. Szklarzewicz J, Jurowska A, Hodorowicz M, Gryboś R, Matoga D. Role of co-ligand and solvent on properties of V(IV) oxido complexes with ONO Schiff bases. Journal of Molecular Structure. 2019; 1180:839-848.

29. Sheldrick GM. SHELXT - Integrated space-group and crystal-structure determination. Acta Crystallographica Section A Foundations and Advances. 2015; 71:3-8.

30. Sheldrick GM. Crystal structure refinement with SHELXL. Acta Crystallographica Section C Structural Chemistry. 2015; 71:3-8.
31. Brandenburg K, Putz H. DIAMOND. Crystal Impact GbR, Bonn, Germany. 2005.

32. Tsiamis C, Voulgaropoulos B, Charistos D, Voutsas GP, Kavounis C. Ligand reactivity, substituent effects and solvent interactions in the spectra and structure of some oxovanadium (V) chelates with Schiff bases. Proof for dimeric species. Polyhedron. 2000; 19:2003-2010.

33. Diamantis AA, Frederiksen JM, Salam MA, Snow MR, Tiekink ERT. Structures of 2 Vanadium (V) Complexes With Tridentate Ligands. Australian Journal of Chemistry. 1986; 39:1081-1088.

34. Wang W, Wang X, Liu HX, Tan MY. Synthesis, characterization and crystal structure of an oxovanadium (V) complex with the Schiff base N-benzoylacetone-M-chlorobenzoylhydrazone. Journal of Coordination Chemistry 1995; 36:49-55. 